\title{
Predicting macrofaunal species distributions in estuarine gradients using logistic regression and classification systems
}

\author{
J. Ellis ${ }^{1, *}$, T. Ysebaert ${ }^{2}$, T. Hume ${ }^{3}$, A. Norkko ${ }^{3}$, T. Bult ${ }^{4}$, P. Herman $^{2}$, S. Thrush ${ }^{3}$, \\ J. Oldman ${ }^{3}$ \\ ${ }^{1}$ Crydium Group Ltd, 10 Linden Place, St John's, Newfoundland A1B 2S8, Canada \\ ${ }^{2}$ Netherlands Institute of Ecology, Centre for Estuarine and Coastal Ecology, PO Box 140, 4400 AC Yerseke, The Netherlands \\ ${ }^{3}$ National Institute of Water and Atmospheric Research, PO Box 11-115, Hamilton, New Zealand \\ ${ }^{4}$ Netherlands Institute for Fisheries Research, PO Box 681970 AB, IJmuiden, The Netherlands
}

\begin{abstract}
There is a growing need to predict ecological responses to long-term habitat change. However, statistical models for marine soft-substratum ecosystems are limited, and consequently there is a need for the development of such models. In order to assess the utility of statistical modelling approaches for predicting likely changes in species distributions under varying environmental conditions, we tested the utility of logistic modelling and classification approaches. We successfully developed models relating the presence/absence of common intertidal macrofauna to changing environmental variables such as sediment characteristics, depth/elevation, tidal currents and wind-wave (i.e. wind-generated wave activity) disturbance. The final model for each species contained between 1 and 6 variables, where the percentage correctly predicted was moderate to high, ranging from 59 to $97 \%$. We were also able to identify relationships between higher level variables such as estuary type, basin morphometry and catchment-draining processes in driving macrobenthic community composition; however, we were unable to fully test the utility of the classification approach due to differences in the scale at which the macrobenthic data was collected and the scale of the higher level physical variables. These models were developed and tested using data that covered a range of environmental conditions in 5 estuaries in New Zealand. Such broad-scale statistical models play a critical role in our understanding of the likely effects of large-scale habitat change. However, a greater understanding of the fine-scale mechanistic controls on species distributions such as life-history characteristics, density information and biotic interactions would potentially lead to the development of more sensitive models.
\end{abstract}

KEY WORDS: Logistic regression - Statistical modelling · Classification systems · Benthic macrofauna $\cdot$ Sedimentation $\cdot$ Estuary $\cdot$ Macroecology $\cdot$ New Zealand

\section{INTRODUCTION}

Estuaries are complex systems, rich in structural and biological diversity, that occupy the interface between terrestrial and marine environments (Levin et al. 2001). They are characterised by widely varying and often unpredictable hydrological, morphological and chemical conditions (Day et al. 1989). As a consequence, benthic macrofauna that inhabit these environments experi- ence a large range of temporal and spatial variability in environmental conditions. Distributions of benthic animals are often hard to predict due to complex relationships between physical parameters, recruitment success, and biological interactions such as competition and predation. However, the development of models that enable ecological variables to be related to environmental factors is a desirable goal, and would increase our ability to sustainably manage resources. 
In soft-sediment ecology there is a long history of studies that have investigated macrofaunal community distributions in relation to changes in environmental variables, including studies that investigated community dominance patterns (Warwick 1986) and functional changes (Pearson \& Rosenberg 1978), and approaches that related the distribution and abundance of macrofauna to sediment particle size (Thorson 1950, Rhoads \& Young 1970). Deterministic models that are able to predict the distribution and abundance of species relative to changes in environmental parameters have, however, proved difficult to construct due to difficulties in identifying the underlying causal mechanisms controlling species distributions. This is further complicated by the fact that animals modify their physical environment, and that many physical parameters co-vary.

Recently, a number of studies have developed effective statistical models of broad-scale benthic distribution patterns within estuaries based on salinity, depth, current velocity and sediment characteristics. For example, Ysebaert et al. (2002) used logistic regression to derive response surfaces of the probability of occurrence (p) for 20 common macrobenthic species in the Schelde estuary, The Netherlands. Thrush et al. (2003) developed species-specific models to predict $\mathrm{p}$ and maximum density relative to sediment mud content for 13 common macrofaunal species in a number of New Zealand estuaries. While these statistical techniques are not new, they have rarely been applied to marine systems. Both these studies successfully forecasted changes in the distribution of macrofaunal species arising from long-term changes in habitat type, for marine systems. Statistical modelling can therefore provide a useful tool to relate ecological variables to environmental factors.

Another approach to predicting the distribution of communities in response to physical attributes is the use of classification systems. Classification systems have been applied to terrestrial ecosystems, where higherlevel controlling factors such as climate, topography and geology are assumed to largely determine organisation and functioning of these systems (Bailey 1983, Klijn \& Udo de Haes 1994). Such classifications aim at describing the ecosystem pattern based on a conceptual view of how ecosystems are organised, and result in a hierarchical classification that allows large-scale classes to be subdivided into smaller-scale classes. Classifications that are based on 'controlling factors' have been specifically promoted as spatial frameworks for environmental management activities, facilitating the evaluation of unique areas, development of data inventories, and the interpolation of information from specific sites to larger areas. However, in marine and estuarine ecology, this technique has rarely been applied.

A classification system of New Zealand estuaries based on a large database of the physical attributes of
New Zealand's estuaries collected at a relatively coarse scale (1:50 000) has been developed (Hume \& Snelder 2001). General linear modelling (GLM) techniques have been successfully used to relate the physical properties of estuaries (such as estuary type, area, tidal influence, catchment area, catchment rainfall, intertidal area and temperature) with the size and diversity of wader populations (Whelan et al. 2003). Analysis revealed strong positive relationships between the size and diversity of a wader population and estuary area, and a negative relationship with freshwater runoff. Such information can be used by managers to predict which estuaries in New Zealand are important in maintaining large populations and high species diversity of migratory and non-migratory waders. However, this technique has not so far been used to develop species-specific models of occurrence.

The aims of this study were therefore to (1) test the applicability of logistic regression models to benthic macrofauna in different estuarine systems, and (2) examine the species distributions as a function of small/medium-scale (sediment content, organic matter) and large-scale (e.g. estuary type and catchment area) environmental variables. Such data would enable the prediction of species-specific macrobenthic distributions using statistical modelling approaches and large-scale variables derived from hierarchical classification systems, and indicate whether estuary type influences the relationship between a species and its environment.

\section{MATERIALS AND METHODS}

Study sites. Whitford is a small $\left(11.06 \mathrm{~km}^{2}\right)$ system on the North Island of New Zealand. It is comprised of 3 tidal creeks (Mangemangeroa, Turanga, Waikopua) which drain into a broad, shallow, outer embayment (Fig. 1). Extensive muddy intertidal flats are dissected by narrow drainage channels in the upper tidal creeks. The outer embayment has a higher proportion of subtidal habitats, and (due to heavy wind-wave disturbance) the intertidal flats are comprised of sandy sediments. This estuary is presently experiencing high rates of sedimentation due to urbanisation of the surrounding Whitford catchment, and this has resulted in significant inputs of sediments to the estuary (Ellis et al. 2004). The upper tidal flats are experiencing high net accumulations of muddy terrigenous sediments, with rates as high as $23 \mathrm{~mm} \mathrm{yr}^{-1}$ (Oldman \& Swales 1999). A total of 90 different sites throughout the estuary were sampled for benthic macrofauna and associated sediment characteristics (Fig. 1). The sites were positioned in the subtidal zone in the main embayment, in the outer intertidal sandflats, in the main outer 
channels, in the inner estuary intertidal mudflats (Mangemangeroa, Turanga, Waikopua), and in the inner estuary subtidal channels. Therefore, the data set covered a range of environmental conditions and enabled general models of species changes to abiotic variables to be generated.

Macrobenthos. To quantify benthic community structure at each site, three $15 \mathrm{~cm}$ diameter cores, extending $13 \mathrm{~cm}$ into the sediment, were taken at $5 \mathrm{~m}$ intervals. Intertidal samples were collected in October and subtidal samples in November 2000. The macrofaunal samples were sieved through a $0.5 \mathrm{~mm}$ mesh, preserved in $70 \%$ isopropyl alcohol, and stained with $0.2 \%$ Rose Bengal. Macrofauna retained on the sieves were sorted and identified to the lowest possible level.

Environmental variables. For each site, we also recorded or calculated the following abiotic environmental variables: depth/elevation, sediment characteristics (organic matter, chlorophyll $a$, mud content and grain size), current velocities (maximum ebb and flood-current velocities), and wave climate. Depth ranged from -3.7 to $6.5 \mathrm{~m}$ (relative to chart datum). Therefore, negative values were adjusted to positive values by adding $3.7 \mathrm{~m}$.

Sediment cores. Sediment core samples $(2.0 \mathrm{~cm}$ diameter, $2.0 \mathrm{~cm}$ deep) were obtained at each site near each macrofaunal core and subsequently analysed for percentage volatile organic matter, chlorophyll $a$, and sediment grain size. Organic content of the sediment was measured as the weight loss after ignition at $440^{\circ} \mathrm{C}$ for $12 \mathrm{~h}$, of samples that had been previously dried at $60^{\circ} \mathrm{C}$ for $6 \mathrm{~h}$. Chlorophyll a was determined as a measure of food availability for benthic animals; it was extracted from sediments by boiling in $95 \%$ ethanol, and then measured spectrophotometrically. An acidification step was used to separate degradation products from chlorophyll a (Sartory 1982). Sediment particlesize was determined for samples that had been predigested (6\% hydrogen peroxide for $48 \mathrm{~h}$ ) to remove organic matter, and dispersed using Calgon. Subsequently, percentage volumes for sediment fractions (gravel, coarse, medium and fine sand, silt and clay) were determined by wet-sieving (particle size $>63 \mu \mathrm{m}$ ). A Galai particle-analyser (Galai Cis-100; Galai Productions) was used to measure the size of particles < $63 \mu \mathrm{m}$. Particle diameter was determined by counting 750 000 particles per sample.

Tidal and wave climate data. In shallow estuaries such as Whitford, tidal currents are, in themselves, often incapable of resuspending sediments, but in combination with near-bed orbital currents generated by small wind-driven waves, sediment transport can occur (Bell et al. 1997). Depth-averaged currents (cm $\mathrm{s}^{-1}$ ) for mean ebb and flood tides were generated from a 3 dimensional dispersal (3DD) model numerical

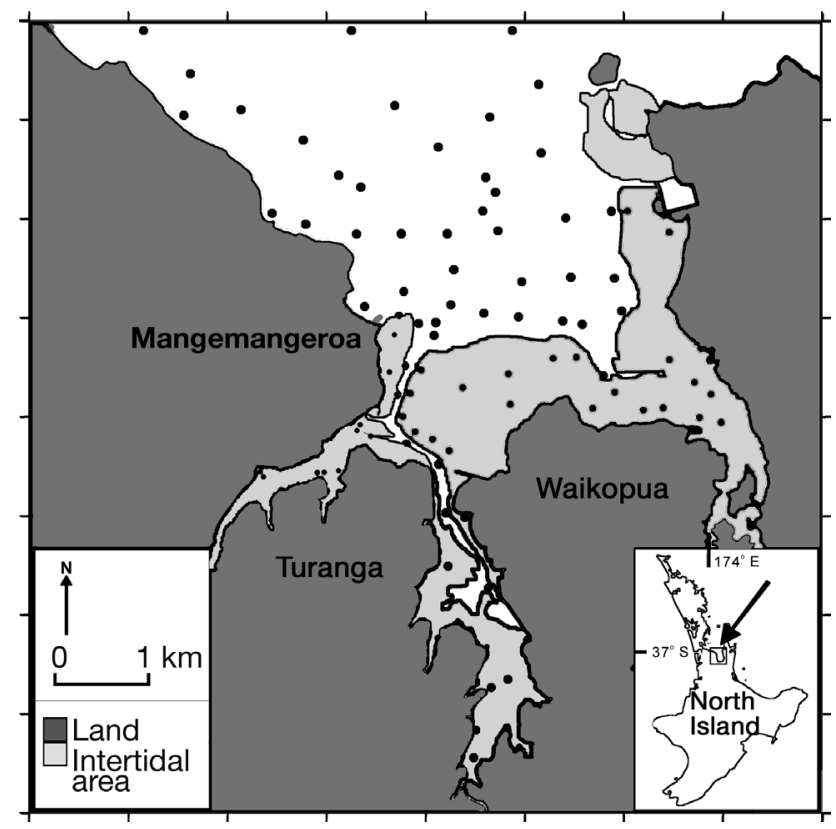

Fig. 1. Locations of the 90 sites sampled for benthic macrofauna and associated physical parameters in Whitford embayment, North Island, New Zealand (1 km grid scale)

model (Black 1995) of the estuary (previously set up and calibrated as part of another study: Oldman \& Swales 1999). The numerical model WGEN (Black 1997), used to predict wave growth subject to wind stress, was used to generate a time series of significant wave height $\left(U_{\text {sig }}\right)$ and peak spectral-wave period $\left(\mathrm{T}_{\mathrm{p}}\right)$ from wind records along with the orbital wave speed at the seabed $\left(U_{\mathrm{b}}{ }^{3}, \mathrm{~cm} \mathrm{~s}^{-1}\right)$. The critical wave orbital speed for initiation of sediment suspension $\left(U_{\mathrm{w}, \text { crit }}\right)$ was predicted from Komar \& Millers (1975) equation using the grain size and orbital wave speeds calculated for each model cell. The model grid cell size was $20 \times 20 \mathrm{~m}$ (Oldman \& Swales 1999).

Landscape variables. A database developed as part of the NZ Estuarine Environment Database (NZED) (Hume \& Snelder 2001) provided information on the physical attributes of estuaries. The classification identifies classes of estuaries that display significant variation in hydrodynamic and main controlling processes (e.g. high tide area, estuary shape, amount of runoff). The 8 estuary types comprise tidal lagoon, embayment, drowned valley, sound, coastal lake, tidal river, tidal creek and fjord. The Whitford system is comprised of 3 tidal creeks and an open embayment. For each of these subenvironments, the following attributes were calculated: estuary type (a categorical variable), high tide area $\left(\mathrm{km}^{2}\right)$, coastline length $(\mathrm{km})$, percentage of mangrove and percentage of intertidal area, land catchment area $\left(\mathrm{km}^{2}\right)$, mean catchment rainfall $\left(\mathrm{mm} \mathrm{yr}^{-1}\right)$, and mean runoff $\left(\mathrm{mm} \mathrm{yr}^{-1}\right)$. 
Statistical analysis. To illustrate the relevant species distributions across environmental gradients, we used simple box- and whisker-plots (see Fig. 3) for 13 representative macrobenthic species. However, we also investigated species habitat preferences using multivariate techniques. The variability in the existing macrofaunal community structure in relation to changing environmental variables was examined using canonical correspondence analysis and partial canonical correspondence analysis using CANOCO (Ter Braak 1986, 1987). Environmental variables included sediment grain size, sediment organic content, chlorophyll a content, tide and wave velocities and landscape variables including catchment area, estuary type, mean runoff, mean rainfall, coastline length, high tide area, and percentage of intertidal and mangrove habitat. We also calculated similarity percentages (SIMPER; Warwick et al. 1991) based on Bray-Curtis similarities calculated from the raw data to determine species habitat affinity for existing macrobenthic distributions. From these ordinations we were able to determine the relationships between groups of species with preferences for particular sites/habitats. The ordination and SIMPER results (see Table 2, Fig. 4) are therefore presented to further help evaluate the accuracy of the model-calculated probability of occurrence (p) compared to the actual observed macrobenthos distribution.

Logistic regression. Logistic regression falls within the general framework of GLM, and can be used to analyse the relationship between a binary response variable and 1 or more explanatory variables (Ysebaert el al. 2002). Logistic regression applies maximum likelihood estimation after transforming the dependent variable into a logit variable. In this way, logistic regression estimates the probability that a certain event will occur.

In order to evaluate the applicability of the models developed by Ysebaert et al. (2002), we also used logistic regression (Cox 1970, Hosmer \& Lemeshow 1989) based on binary (presence/absence) data to model the probability of occurrence of 20 species in relation to abiotic environmental predictors. While the total number of species recorded at Whitford was 163, we could only fit meaningful response curves to 20 of these, because many species were present in low numbers, exhibited skewed distributions, or were very rare, with only a few individuals observed. Therefore, a response

Table 1. Sediment characteristics (means \pm SE), depth, tidal and wind-wave data associated with main marine habitat types (identified from ordination analysis of Whitford embayment and sub-estuaries. $U_{\text {sig }}=$ significant wave height; $\mathrm{T}_{\mathrm{p}}=$ peak spectral-wave period; $U_{\mathrm{b}}{ }^{3}=$ orbital-wave speed at seabed; $U_{\mathrm{w}, \mathrm{crit}}=$ critical orbital-wave speed for initiation of sediment suspension. Average no. of taxa and individuals per core and average Bray-Curtis dissimilarity in macrobenthic community composition between habitats are also presented

\begin{tabular}{|c|c|c|c|c|c|c|}
\hline \multirow[t]{2}{*}{ Parameter } & \multicolumn{2}{|c|}{ Estuary } & \multirow[b]{2}{*}{$\begin{array}{l}\text { Intertidal } \\
(\mathrm{n}=40)\end{array}$} & \multicolumn{2}{|r|}{ Embayment } & \multirow[b]{2}{*}{$\begin{array}{l}\text { Subtidal deep } \\
(>3 \mathrm{~m})(\mathrm{n}=17)\end{array}$} \\
\hline & $\begin{array}{l}\text { Intertidal } \\
(\mathrm{n}=12)\end{array}$ & $\begin{array}{c}\text { Channel } \\
(\mathrm{n}=8)\end{array}$ & & $\begin{array}{l}\text { Channel } \\
(\mathrm{n}=4)\end{array}$ & $\begin{array}{l}\text { Subtidal shallow } \\
\quad(<3 \mathrm{~m})(\mathrm{n}=9)\end{array}$ & \\
\hline \multicolumn{7}{|l|}{ Abiotic characteristics } \\
\hline Clay/silt (\%) & $64.1(7.8)$ & $15.5(3.9)$ & $2.5(0.5)$ & $8.4(2.1)$ & $3.8(1.3)$ & $33.3(5.0)$ \\
\hline Sand $(\%)$ & $35.3(7.8)$ & $70.4(5.6)$ & $93.2(1.4)$ & $72.7(13.2)$ & $93.7(1.9)$ & $65.3(5.3)$ \\
\hline Gravel (\%) & $0.2(0.1)$ & $14.1(7.5)$ & $4.2(1.4)$ & $18.9(11.6)$ & $2.4(1.8)$ & $1.4(0.6)$ \\
\hline Chlorophyll a (mg g $\left.{ }^{-1}\right)$ & $10.8(0.5)$ & $8.1(1.4)$ & $7.9(0.6)$ & $3.9(1.0)$ & $7.7(1.0)$ & $5.3(0.4)$ \\
\hline Organic content (\%) & $5.8(0.9)$ & $2.2(0.2)$ & $1.0(0.1)$ & $1.3(0.1)$ & $0.7(0.1)$ & $2.4(0.2)$ \\
\hline Depth (m) & 1.8 & -2.1 & 1.8 & -3.0 & -1.7 & -4.7 \\
\hline Depth (positive) & 1.9 & 5.8 & 1.9 & 6.7 & 5.4 & 8.4 \\
\hline Ebb velocity $\left(\mathrm{m} \mathrm{s}^{-1}\right)$ & 0.13 & 0.32 & 0.16 & 0.27 & 0.16 & 0.12 \\
\hline Flood velocity $\left(\mathrm{m} \mathrm{s}^{-1}\right)$ & 0.15 & 0.30 & 0.15 & 0.25 & 0.15 & 0.11 \\
\hline$U_{\text {sig }}(\mathrm{m})$ & 0.21 & 0.25 & 0.32 & 0.34 & 0.35 & 0.28 \\
\hline $\mathrm{T}_{\mathrm{p}(\mathrm{s})}$ & 1.02 & 1.44 & 1.74 & 1.69 & 1.64 & 1.33 \\
\hline$U_{\mathrm{b}}^{3}\left(\mathrm{~cm} \mathrm{~s}^{-1}\right)$ & 0.05 & 0.03 & 0.22 & 0.06 & 0.05 & 0.02 \\
\hline$U_{\mathrm{w}, \mathrm{crit}}\left(\mathrm{m} \mathrm{s}^{-1}\right)$ & 1.31 & 1.74 & 1.76 & 1.90 & 1.89 & 1.81 \\
\hline \multicolumn{7}{|l|}{ Macrofauna } \\
\hline No. of taxa & $11.2(1.7)$ & $11.6(0.9)$ & $18.1(1.0)$ & $25.3(2.3)$ & $11.0(2.0)$ & $12.7(0.6)$ \\
\hline No. of individuals & $50.0(8.6)$ & $32.2(11.6)$ & $60.5(8.2)$ & $80.8(21.6)$ & $21.8(5.7)$ & $14.9(2.6)$ \\
\hline \multicolumn{7}{|l|}{ Dissimilarity between sites } \\
\hline Intertidal & 0 & 82.9 & 82.8 & 77.4 & 90.9 & 91.1 \\
\hline Channel & & 0 & 74.6 & 73.8 & 79.6 & 83.3 \\
\hline Embayment Intertidal & & & 0 & 80.7 & 82.8 & 90.4 \\
\hline Channel & & & & 0 & 81.3 & 77.9 \\
\hline Shallow & & & & & 0 & 79.3 \\
\hline Deep & & & & & & 0 \\
\hline
\end{tabular}


surface for each of these 20 macrobenthic species on each of the independent variables was generated by logistic regression using the statistical package SAS (SAS Institute 1989). The regression parameters were estimated using the maximum likelihood method. Besides response curves for each single abiotic variable, all variables were simultaneously used in a stepwise, multiple logistic-regression analysis to derive a model that would predict the presence or absence of macrobenthic species. Because the wave data is correlated with the grain size information and depth data, the analyses were run separately with and without wave variables. (For full details see Ysebaert et al. 2002).

In order to validate the utility of the models, we selected additional data from other New Zealand estuaries. Data from these surveys were also collected in October 2000 (to avoid seasonal differences in macrobenthic trends), using the same methodology as described above. We selected sites that covered a range of environmental conditions including wind/wavedominated intertidal sandflats (Manukau Harbour, 6 sites), intertidal benthic data collected from sheltered mudflats within a tidal creek (Puhinui Creek, 3 sites), and 5 intertidal and 3 subtidal sites in a more tidally dominated system (Mahurangi Harbour) (Fig. 2). To determine the accuracy of the models developed from the Whitford database, the distributions predicted from the environmental conditions for each location were then compared to the observed distributions using the additional validation data. We present the calculated probability of occurrence (p) versus actual occurrence for 8 contrasting macrobenthic species representative of different functional modes, with varying distributions across environmental gradients, which contribute significantly to total density and biomass.

\section{RESULTS}

\section{Model development}

\section{Characterisation of abiotic environment}

Physical characteristics varied considerably across Whitford estuary (Table 1). Mud content was significantly higher in the upper estuary intertidal areas of Mangemangeroa, Waikopua and Turanga Creeks than in the other habitats, with an average silt/clay content of $64 \%$. Associated with the higher mud content of the sediment were higher chlorophyll $a$ and organic contents of the sediments. These upper, sheltered, tidal creeks were also less exposed to wind-wave activity. Most samples were taken from the 'embayment intertidal' area, which was predominantly sandy (93\% sand), with the greatest wind/wave disturbance char- acterised by high orbital speeds at the seabed $\left(U_{\mathrm{b}}{ }^{3}=\right.$ $0.22 \mathrm{~cm} \mathrm{~s}^{-1}$ ). Interestingly, the channel sites in both the upper estuary and embayment habitats had the highest percentages of gravel due to high tidal-flows in these environments. The subtidal areas in the open embayment differed, with the deeper $(<3 \mathrm{~m})$ habitats having a greater proportion of mud in their sediment $(33 \%)$. A likely mechanism is the inability of windwave disturbance to penetrate to the seabed at these deeper sites and (in combination with tidal velocity) initiate sediment transport.

\section{Observed distribution of macrobenthos along environmental gradients}

Fig. 3 presents the observed distribution of 13 macrobenthic species as a function of environmental variables such as depth, silt/clay content and critical orbital-wave velocity. While some species, e.g. Aquilaspio aucklandica, were ubiquitous or widespread across varying habitat types, most displayed clear differences in abundance as a function of sediment type. Sandy sediments were dominated by bivalve species Macomona liliana, Austrovenus stutchburyi, Nucula hartvigiana and the crustacean Colurostylis lemurum. Sediments comprised of fine silts and clays were dominated by the amphipod Paracorophium excavatum, oligochaetes, nereid polychaetes, the capitellid polychaete Heteromastus filiformis and crab species such as the mud crab Helice crassa. Most species were observed in the intertidal zone; however some, such as Theora lubrica, were typically subtidal. Oligochaetes also showed a wider distribution as a function of depth gradients. With respect to wind-wave disturbance, 1 polychaete, Aonides oxycephala, displayed a clear association with increasing orbital speed at the seabed $\left(U_{\mathrm{b}}{ }^{3}\right)$. Bivalve species, which occur in greatest abundance on exposed intertidal sandflats, also became more dominant with increasing wind-wave disturbance. As there were no clear patterns of variation in species distributions as a function of tidal velocity and chlorophyll a content of the sediment, no box-plot figures are provided for these parameters.

Multivariate techniques revealed similar associations between species and habitat type. The first 4 axes, based on the initial unconstrained correspondence analysis, accounted for $76 \%$ of the total variation in macrofaunal community composition across the Whitford sites. Based on species composition, sites clustered into 6 habitats reflecting differing sediment types and levels of physical forcing (Fig. 4). Sediments containing high percentages of mud generally occur in areas experiencing low levels of physical forcing by tidal currents and waves. Such depositional environ- 

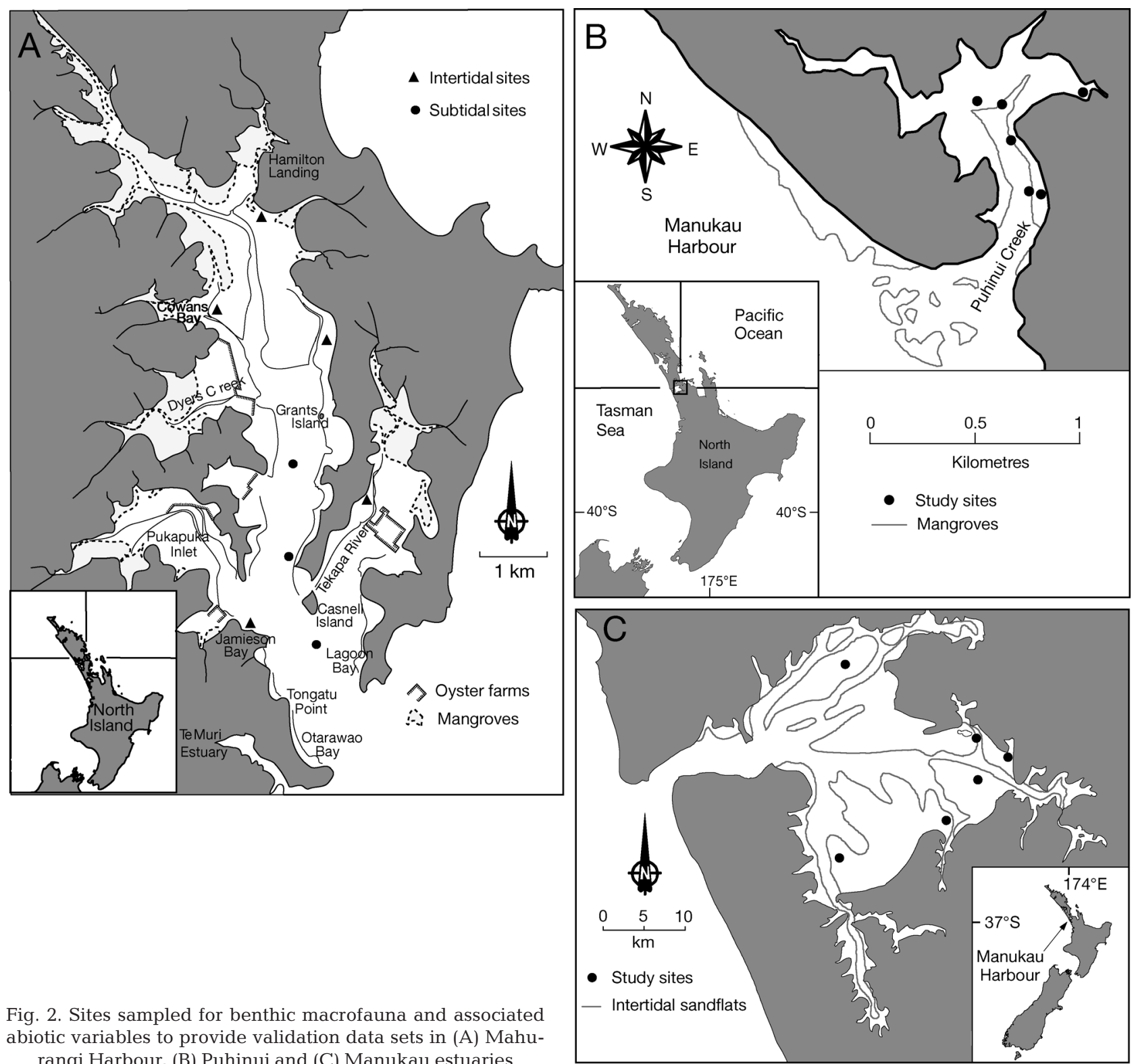

Fig. 2. Sites sampled for benthic macrofauna and associated abiotic variables to provide validation data sets in (A) Mahurangi Harbour, (B) Puhinui and (C) Manukau estuaries

ments are typically found in the upper reaches of estuaries and in the deeper subtidal areas at the mouths of estuaries. These habitats were differentiated in the ordination and were characterised by higher mud and organic contents of the sediment. Variables derived from the NZED such as percentage mangrove, mean run-off and rainfall, and estuary type were also key variables in differentiating these habitats. In contrast, the main intertidal flats ('embayment intertidal') were characterised by sandy sediments, reflecting their exposure to wind-wave disturbance. Although showing overlap, the subtidal sites in the main Whitford embayment were also separated in the ordination on Axis 2 of Fig. 4 ('Embayment deep', 'Embayment shallow', and 'Embayment channel'). All these distinct

habitats were found to support contrasting macrofaunal communities (Table 2). The differences in macrobenthic assemblages between habitats were very large, as indicated by the high average dissimilarity, which ranged from 74 to $91 \%$ (Table 1 ).

In the 'estuary intertidal' habitats the top 5 dominant taxa as determined by SIMPER accounted for $73 \%$ of the within-habitat variability (Table 2); 2 species, the amphipod Paracorophium excavatum and the mud crab Helice crassa, explained nearly $50 \%$ of this variability. Other species associated in these upper 'estuary intertidal' habitats, which were characterised by high mud content and low physical forcing, were the spionid polychaete Aquilaspio aucklandica, nereid polychaetes, and the capitellid polychaete Heteromas- 
tus filiformis. Some taxa were obviously widespread across different habitats, for example $A$. aucklandica was also dominant in the 'estuary subtidal' as well as the 'embayment intertidal' sandflats. Sandflat habitats
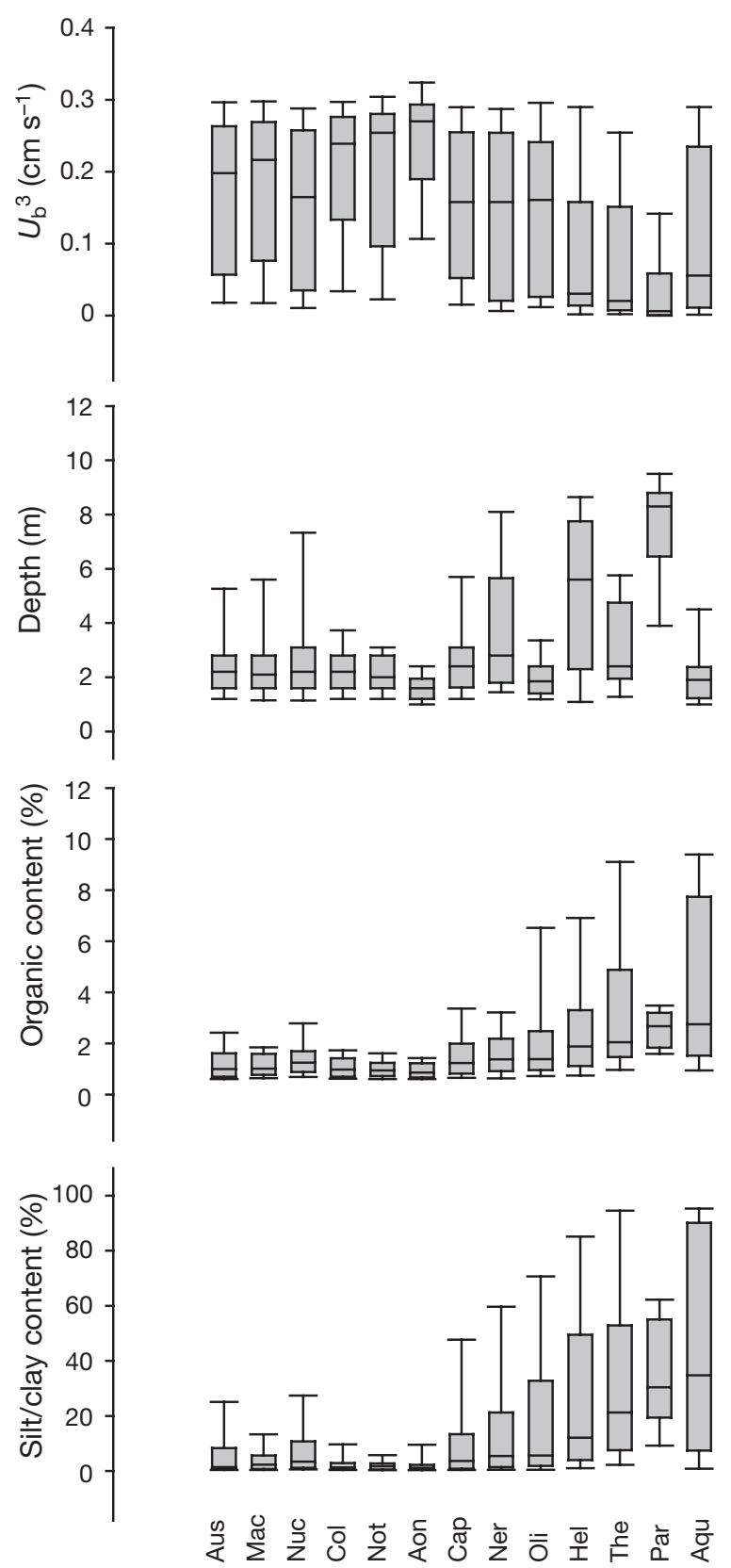

Fig. 3. Distribution of 13 macrobenthic species from Whitford estuary as a function of silt/clay content, organic content, depth, and wave disturbance. $U_{\mathrm{b}}{ }^{3}$ : orbital wave speed. Species presented in order (left to right) of increasing sensitivity to silt/clay. Aus: Austrovenus stutchburyi; Mac: Macomona liliana; Nuc: Nucula hartvigiana; Col: Colurostylis lemurum; Not: Notoacmea helmsii; Aon: Aonides oxycephala; Cap: capitellid; Ner: nereid; Oli: oligochaete; Hel: Helice crassa; The: Theora lubrica; Par: Paracorophium excavatum; Aqu: Aquilaspio aucklandica
Table 2. Rankings of the 5 most dominant macrofauna in each habitat category in Whitford estuary determined by similarity-percentage analysis. \%: explained; Cumul. \%: cumulative $\%$ explained

\begin{tabular}{|c|c|c|c|}
\hline $\begin{array}{l}\text { Habitat and dominant } \\
\text { taxa }\end{array}$ & $\begin{array}{l}\text { Faunal } \\
\text { group }\end{array}$ & $\%$ & Cumul. \% \\
\hline \multicolumn{4}{|l|}{ Estuary } \\
\hline \multicolumn{4}{|l|}{ Intertidal } \\
\hline Paracophium excavatum & Amphipod & 26.5 & 26.5 \\
\hline Helice crassa & $\mathrm{Crab}$ & 22.3 & 48.8 \\
\hline Aquilaspio aucklandica & Polychaete & 12.0 & 60.8 \\
\hline Nereid & Polychaete & 6.8 & 67.6 \\
\hline Heteromastus filiformis & Polychaete & 5.6 & 73.2 \\
\hline \multicolumn{4}{|l|}{ Channel } \\
\hline Capitellid & Polychaete & 21.6 & 21.6 \\
\hline Oligochaete & Oligochaete & 13.2 & 34.8 \\
\hline Aquilaspio aucklandica & Polychaete & 10.8 & 45.6 \\
\hline Helice crassa & Crab & 8.6 & 54.2 \\
\hline Cossura sp. & Polychaete & 8.1 & 62.3 \\
\hline \multicolumn{4}{|l|}{ Embayment } \\
\hline \multicolumn{4}{|l|}{ Intertidal } \\
\hline Macomona liliana & Bivalve & 13.0 & 13.0 \\
\hline Aquilaspio aucklandica & Polychaete & 10.6 & 23.6 \\
\hline Austrovenus stutchburyi & Bivalve & 9.5 & 33.1 \\
\hline Nucula hartvigiana & Bivalve & 9.3 & 42.4 \\
\hline Colurostylis lemurum & Cumacean & 6.0 & 48.4 \\
\hline \multicolumn{4}{|l|}{ Channel } \\
\hline Nucula hartvigiana & Bivalve & 13.3 & 13.3 \\
\hline Heteromastus filiformis & Polychaete & 11.7 & 25.0 \\
\hline Glycerid & Polychaete & 10.3 & 35.3 \\
\hline Boccardia syrtis & Polychaete & 10.0 & 45.3 \\
\hline Oligochaete & Oligochaete & 8.4 & 53.7 \\
\hline \multicolumn{4}{|l|}{ Shallow } \\
\hline Waipirophoxus waipiro & Amphipod & 41.0 & 41.0 \\
\hline Aricidea sp. & Polychaete & 11.4 & 52.4 \\
\hline Tanaid & Crustacean & 9.6 & 62.0 \\
\hline Exogonid & Polychaete & 9.1 & 71.1 \\
\hline Cossura sp. & Polychaete & 4.2 & 75.3 \\
\hline \multicolumn{4}{|l|}{ Deep } \\
\hline Theora lubrica & Bivalve & 20.0 & 20.0 \\
\hline Cossura sp. & Polychaete & 13.4 & 33.4 \\
\hline Lubrinereid & Polychaete & 12.8 & 46.2 \\
\hline Waipirophoxus waipiro & Amphipod & 10.7 & 56.9 \\
\hline Sigalionidae & Polychaete & 9.2 & 66.1 \\
\hline
\end{tabular}

were dominated by the bivalve Macomona liliana, $A$. aucklandica, the cockle Austrovenus stutchburyi, the nut shell Nucula hartvigiana and the cumacean Colurostylis lemurum. The top 5 most dominant taxa accounted for $48 \%$ of the variability within the habitat, potentially demonstrating a comparatively high macrobenthic diversity or higher equitability, since a large number of other species would be required to more accurately explain the within-site community variability. The more physically dynamic intertidal sandflats of the 'embayment intertidal' and the inner sheltered mudflats of the 'estuary intertidal' represent contrasting endpoints in a probable range of macrobenthic communities across these varying habitat types. 


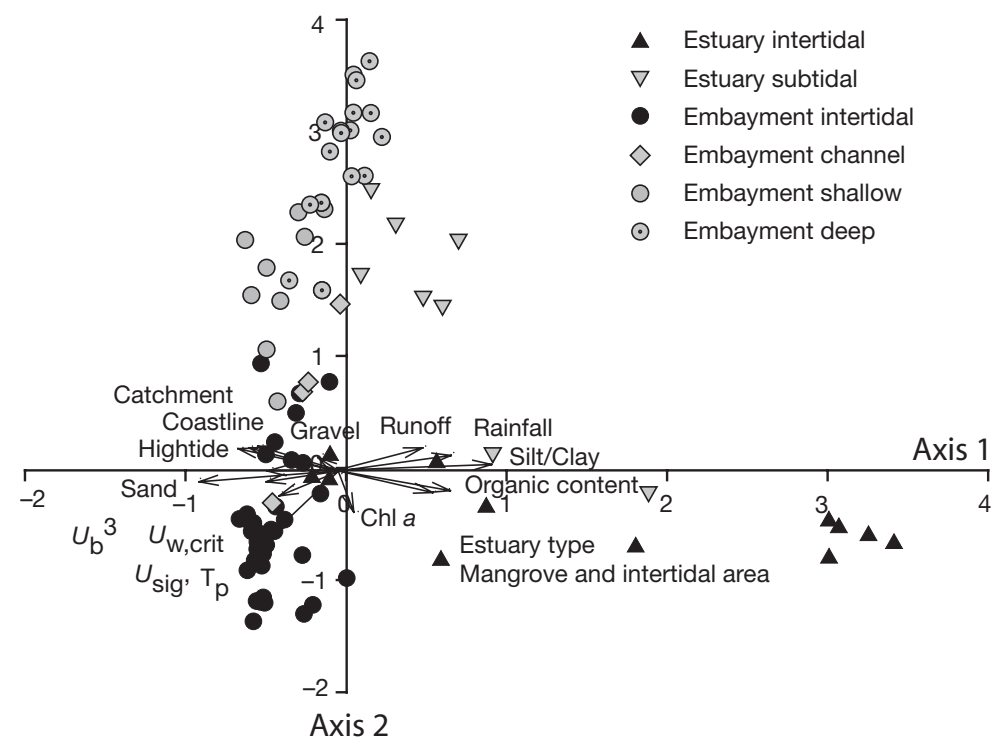

Fig. 4. Canonical correspondence analysis of environmental variables (arrows) and sampling sites (see legend) derived from macrofaunal abundance data for Whitford estuary. Abbreviations as in Table 1

Besides these clear differences in macrofaunal communities between habitats, we also recorded differences in the average diversity and abundance of benthic macrofauna. Although variable, the upper estuarine habitats ('estuary intertidal' and 'estuary channel') and the 'embayment shallow' habitats had the lowest average species diversity. The upper estuarine habitats have very high sedimentation rates and correspondingly high mud contents of the sediments, while the shallow subtidal habitat is an area likely to experience prolonged exposure to elevated suspended sediments and wind-wave disturbance. The intertidal sandflats ('embayment intertidal') as well as the

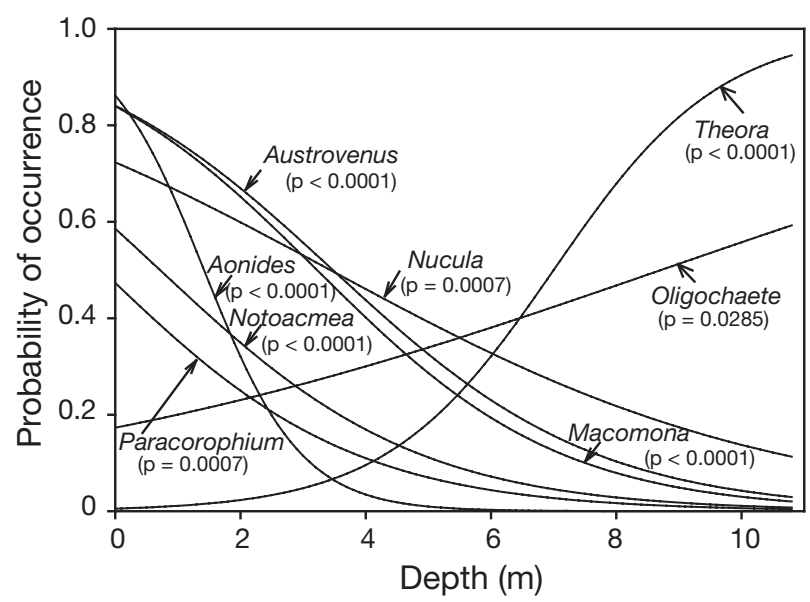

Fig. 5. Probability of occurrence (p) of macrobenthic species in relation to (model) depth, fitted using logistic regression for macrofauna from Whitford estuary. Full specific names in legend to Fig. 3 'embayment channel' habitats had the highest average species diversity and abundances of benthic animals.

Model-predicted distribution of macrobenthos along environmental gradients

Model-predicted response curves generated using logistic regression were derived for all 20 macrobenthic species. As an example, significant response surfaces for 8 macrobenthic species are shown based on model depth, grain size and orbital speed at the seabed in Figs. 5 to 7 . The response surfaces (Figs. 5 to 7 ) were in general agreement with the observed distribution of the species (Figs. $3 \& 4$ ), indicating accuracy of the logistic modelling approach. Most macrobenthic species showed a high probability of occurrence at intertidal depths, with only 1 species, Theora lubrica, having its highest probability of occurrence in the subtidal zone (Fig. 5). Species occurrence differed as a function of depth. For example, the probability of occurrence of the polychaete Aonides oxycephala, the amphipod Paracorophium excavatum, and the limpet Notoacmea helmsii was highest at intertidal depths, while the bivalves Austrovenus stutchburyi and Macomona liliana occurred across a broader range of depths, from intertidal to subtidal habitats. The response surfaces in relation to grain size clearly indicated variations as a function of mud content

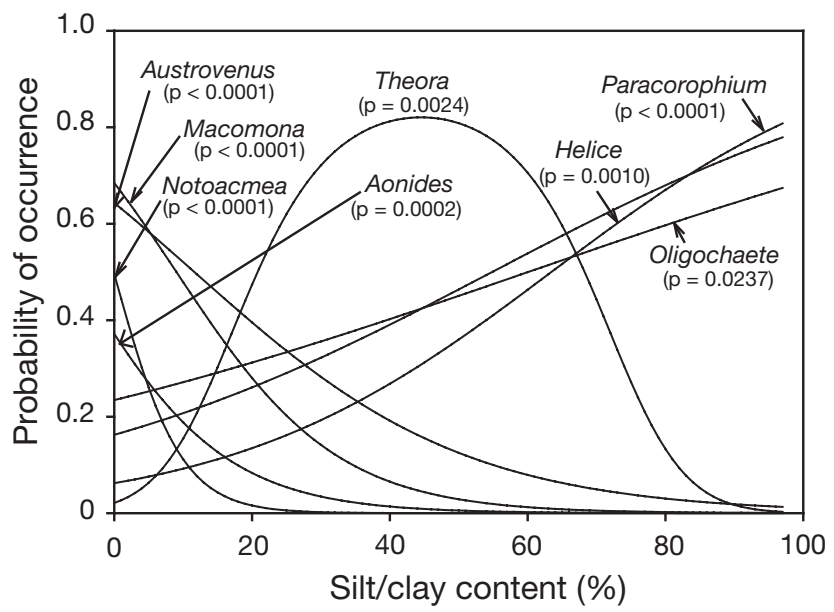

Fig. 6. Probability of occurrence (p) of macrobenthic species in relation to (model) silt/clay content, fitted using logistic regression for macrofauna from Whitford estuary. Full specific names in legend to Fig. 3 


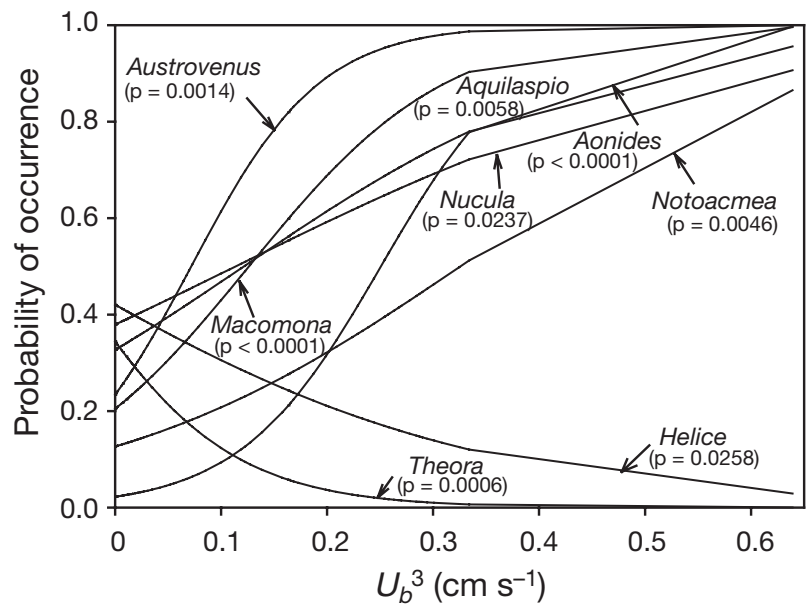

Fig. 7. Probability of occurrence (p) of macrobenthic species in relation to (model) orbital speed $\left(U_{\mathrm{b}}{ }^{3}\right)$ at seabed, fitted using logistic regression for macrofauna from Whitford estuary. Full specific names in legend to Fig. 3

(Fig. 6). The probability of occurrence of 3 species, the amphipod $P$. excavatum, the mud crab Helice crassa, and Oligochaeta was highest in very muddy sediments, again in good agreement with their observed distributions (Fig. 3). The probability of occurrence of the mollusc $N$. helmsii and the polychaete A. oxycephala, was highest in sandy habitats, with little tolerance of increased mud content, while that of bivalve species such as M. liliana and Austrovenus stutchburyi was highest in sandy sediments; however, the cockle $A$. stutchburyi showed a broader tolerance to sediment mud content. For species with unimodal response curves, such as $T$. lubrica, the model suggests a clear optimum at intermediate mud contents. T. lubrica is a predominately subtidal species, and at the deeper sites mud content increased (average content: $33 \%$ ) through the inability of winddriven waves to penetrate to the seabed and (in combination with tidal velocities) initiate sediment transport. Interestingly, while most of the functionally important suspension-feeding bivalve species were sensitive to increased mud content, a unimodal bellresponse surface was exhibited by $T$. lubrica, suggesting its broader tolerance to mud. T. lubrica is an invasive species in New Zealand waters, and a wide tolerance to environmental conditions often characterises invasive species. Response surfaces in relation to wind-wave disturbance (measured as orbital speed

Table 3. Diagnostics for logistic regression models indicating variables that were significant for each species (x), \% correctly predicted (\% CP), and sensitivity (Sen) and specificity (Spec) of the model. S: silt (\%); OC: organic content (\%); chl a: chlorophyll $a\left(\mathrm{mg} \mathrm{g}^{-1}\right) ; \mathrm{D}$ : depth $(\mathrm{m}) ;$ Ebb: ebb velocity $\left(\mathrm{m} \mathrm{s}^{-1}\right) ;$ Flood: flood velocity $\left(\mathrm{m} \mathrm{s}^{-1}\right)$; other abbreviations as in Table 1

\begin{tabular}{|c|c|c|c|c|c|c|c|c|c|c|c|c|c|c|c|}
\hline Species & Silt & $\mathrm{OC}$ & Chl a Depth & $U_{\text {sig }}$ & $\mathrm{T}_{\mathrm{p}}$ & $U_{\mathrm{b}}^{3}$ & $U_{\mathrm{w}, \text { crit }}$ & Ebb Flood & $D \cdot T_{p}$ & S.S & D.D & $U_{\mathrm{b}}{ }^{3} \cdot U_{\mathrm{b}}{ }^{3}$ & $\% \mathrm{CP}$ & Sen & Spec \\
\hline Aquilaspio aucklandica & & & $\mathrm{x}$ & & & & & $\mathrm{x}$ & & & & & 78 & 83 & 69 \\
\hline Macomona liliana & $\mathrm{x}$ & & $\mathrm{x}$ & $\mathrm{x}$ & $\mathrm{x}$ & $\mathrm{x}$ & & & $\mathrm{x}$ & & & & 83 & 83 & 83 \\
\hline Austrovenus stutchburyi & $\mathrm{x}$ & & $\mathrm{x}$ & & & & & & & & & & 73 & 73 & 74 \\
\hline Nucula harvigiana & & & & & & $\mathrm{x}$ & & & & & & & 61 & 62 & 60 \\
\hline Macroclymenella & $\mathrm{x}$ & & & & & & & & & & & & 59 & 47 & 66 \\
\hline Colurostylis lemurum & & & & & & $\mathrm{x}$ & & & & & & $\mathrm{x}$ & 81 & 74 & 84 \\
\hline Oligochaeta & & $\mathrm{x}$ & $\mathrm{x}$ & & & $\mathrm{x}$ & & & & & & & 76 & 60 & 83 \\
\hline Helice crassa & & $\mathrm{x}$ & & & & & & & & & & & 76 & 58 & 83 \\
\hline Nereid & & & $\mathrm{x}$ & & & & & & & & & & 68 & 46 & 78 \\
\hline Orbinia papillosa & & & & & & $\mathrm{x}$ & & & & & & & 73 & 54 & 87 \\
\hline Notacmea helmsii & & & $\mathrm{x}$ & & & & & & & & & & 66 & 33 & 77 \\
\hline Aonides oxycephala & & & $\mathrm{x}$ & & & $\mathrm{x}$ & & & & & & & 88 & 74 & 92 \\
\hline Exogonad & & & $\mathrm{x}$ & & & & & & & & & & 68 & 28 & 80 \\
\hline Cossura sp. & & & $\mathrm{x}$ & $\mathrm{x}$ & & & & & & & & & 83 & 59 & 89 \\
\hline Paracorophium excavatum & & $\mathrm{x}$ & $\mathrm{x}$ & & & & & & & & & & 88 & 67 & 93 \\
\hline Capitella capitata & & $\mathrm{x}$ & $\mathrm{x}$ & & & $\mathrm{x}$ & & & & & $\mathrm{x}$ & & 88 & 67 & 93 \\
\hline Theora lubrica & $\mathrm{x}$ & & $\mathrm{x}$ & & & & & & & $\mathrm{x}$ & & & 97 & 92 & 99 \\
\hline Tanaid & & & $\mathrm{x}$ & & $\mathrm{x}$ & & & & & & $\mathrm{x}$ & & 85 & 54 & 91 \\
\hline Waitangi chelatus & & & $\mathrm{x}$ & & & & & & & & & & 78 & 25 & 87 \\
\hline \multicolumn{16}{|l|}{ Model without waves } \\
\hline Theora lubrica & $\mathrm{x}$ & & $\mathrm{x}$ & & & & & & & $\mathrm{x}$ & & & 93 & 85 & 96 \\
\hline Cossura sp. & & & $\mathrm{x}$ & & & & & & & & & & 84 & 70 & 90 \\
\hline Lumbrinereid & & & $\mathrm{x}$ & & & & & & & & & & 93 & 81 & 96 \\
\hline Austrovenus stutchburyi & $\mathrm{x}$ & & $\mathrm{x}$ & & & & & & & & & & 78 & 76 & 79 \\
\hline \multicolumn{16}{|l|}{ Model without waves, OC } \\
\hline Helice crassa & $\mathrm{x}$ & & $\mathrm{x}$ & & & & & & & & $\mathrm{x}$ & & 82 & 67 & 88 \\
\hline Paracorophium excavatum & $n \mathrm{x}$ & & $\mathrm{x}$ & & & & & & & & & & 87 & 60 & 92 \\
\hline Capitella capitata & $\mathrm{x}$ & & $\mathrm{x}$ & & & & & & & & $\mathrm{x}$ & & 82 & 60 & 89 \\
\hline
\end{tabular}


Table 4. Sediment characteristics, depth, tidal and wind-wave data for Mahurangi, Manukau and Puhinui estuaries. Average number of taxa, individuals, and average Bray-Curtis dissimilarity in macrobenthic community composition between estuaries are also presented

\begin{tabular}{|c|c|c|c|c|}
\hline \multirow{2}{*}{ Parameter } & \multicolumn{2}{|c|}{ ___ Mahurangi } & \multirow{2}{*}{ Manukau } & \multirow{2}{*}{ Puhinui } \\
\hline & Intertidal & Subtidal & & \\
\hline \multicolumn{5}{|l|}{ Abiotic characteristics } \\
\hline Clay/silt (\%) & $27.4(14.1)$ & $48.5(7.1)$ & $5.8(4.4)$ & $95.4(4.7)$ \\
\hline Sand $(\%)$ & $70.3(11.7)$ & $48.5(9.5)$ & $92.5(5.6)$ & $4.5(4.7)$ \\
\hline Gravel (\%) & $2.3(3.6)$ & $2.8(4.5)$ & $1.6(1.5)$ & $0.0(0.0)$ \\
\hline Chlorophyll $a\left(\mathrm{mg} \mathrm{g}^{-1}\right)$ & $11.5(7.2)$ & $4.6(0.04)$ & $6.8(2.2)$ & $21.2(8.2)$ \\
\hline Organic content (\%) & $1.8(0.9)$ & $2.6(1.0)$ & $1.1(0.3)$ & $5.3(0.3)$ \\
\hline Depth (positive) & $3.7(0.9)$ & $10.1(2.6)$ & $2.7(0.9)$ & $0.6(0.5)$ \\
\hline Ebb velocity $\left(\mathrm{m} \mathrm{s}^{-1}\right)$ & $0.11(0.03)$ & $0.27(0.01)$ & $0.27(0.1)$ & $0.02(0.0)$ \\
\hline Flood velocity $\left(\mathrm{m} \mathrm{s}^{-1}\right)$ & $0.11(0.05)$ & $0.25(0.02)$ & $0.26(0.1)$ & $0.02(0.0)$ \\
\hline$U_{\text {sig }}(\mathrm{m})$ & $0.09(0.009)$ & $0.11(0.02)$ & $0.22(0.02)$ & $0.04(0.01)$ \\
\hline $\mathrm{T}_{\mathrm{p}}(\mathrm{s})$ & $1.12(0.08)$ & $1.25(0.13)$ & $1.79(0.08)$ & $0.76(0.0)$ \\
\hline$U_{\mathrm{b}}^{3}\left(\mathrm{~cm} \mathrm{~s}^{-1}\right)$ & $0.05(0.01)$ & $0.00(0.00)$ & $0.24(0.04)$ & $0.01(0.0)$ \\
\hline$U_{\mathrm{w}, \mathrm{crit}}\left(\mathrm{m} \mathrm{s}^{-1}\right)$ & $0.04(0.01)$ & $0.00(0.00)$ & $0.40(0.08)$ & $0.00(0.0)$ \\
\hline \multicolumn{5}{|l|}{ Macrofauna } \\
\hline Number of taxa & $15.7(3.5)$ & $7.3(1.52)$ & $20.7(2.8)$ & $8.7(1.5)$ \\
\hline Number of individuals & $63.6(27.2)$ & $13.9(5.73)$ & $63.9(11.5)$ & $40.4(9.7)$ \\
\hline \multicolumn{5}{|c|}{ Dissimilarity between sites } \\
\hline Mahurangi intertidal & 0 & 69.31 & 64.35 & 85.83 \\
\hline Mahurangi subtidal & & 0 & 84.50 & 85.22 \\
\hline Manukau & & & 0 & 89.25 \\
\hline Puhinui & & & & 0 \\
\hline
\end{tabular}

Table 5. Large-scale characteristics derived from New Zealand Estuarine Environment Database for Manukau, Mahurangi and Puhinui estuaries

\begin{tabular}{|lccc|}
\hline Parameter & $\begin{array}{c}\text { Manukau } \\
\text { Harbour }\end{array}$ & $\begin{array}{c}\text { Mahurangi } \\
\text { Harbour }\end{array}$ & $\begin{array}{c}\text { Puhinui } \\
\text { Creek }\end{array}$ \\
\hline Estuary type & Compound & Compound & Tidal \\
High tide area $\left(\mathrm{km}^{2}\right)$ & 365.60 & 24.57 & 0.64 \\
Coastline length $(\mathrm{km})$ & 459.54 & 85.81 & 7.85 \\
\% Sand & 60.12 & 31.60 & 33.17 \\
\% Mud & 59.60 & 23.16 & 33.17 \\
\% Mangrove & 1.68 & 19.58 & 66.77 \\
\% Intertidal & 61.80 & 51.18 & 99.94 \\
Spring tide range $(\mathrm{mm})$ & 2811 & 2456 & 2811 \\
Mean tide range $(\mathrm{mm})$ & 2199 & 2110 & 2198 \\
Neap tide range $(\mathrm{mm})$ & 1586 & 1763 & 1586 \\
Land catchment area $\left(\mathrm{km}^{2}\right)$ & 1022.60 & 122.16 & 27.23 \\
Mean catchment rainfall $\left(\mathrm{mm} \mathrm{yr}^{-1}\right)$ & 1322.8 & 1622.2 & 1222.6 \\
Mean runoff $\left(\mathrm{mm} \mathrm{yr}^{-1}\right)$ & 385.1 & 592.4 & 222.4 \\
\hline
\end{tabular}

\section{Model prediction using multiple logistic regression}

For each macrobenthic species, a multiple, stepwise logistic regression was run with all abiotic variables combined. Because the wave data is correlated with the grain size and depth data, the analyses were run separately with and without wave variables (Table 3). For a limited number of subtidal sites, tidal velocity and wind-wave calculations could not be calculated. Higher level NZED variables could not be included, as the classification calculates 1 variable for each estuary type and not 1 explanatory variable per site. The final model for each species contained between 1 and 6 variables, whereby the percentage correctly predicted was moderate to high, ranging from 59 to $97 \%$. Sensitivity and specificity were also moderate to high for most species. Sensitivity is defined as the proportion of actual presences that were correctly predicted, while specificity is defined as the proportion of actual absences that were correctly predicted.

\section{Testing logistic regression model}

\section{Validation data}

We selected sites from a number of estuaries to cover a range of environmental conditions and estuary types (Table 4). The Manukau Harbour is a dynamic and rigorous environment (Turner et al. 1995), subject to physical wind-wave and tidal disturbance (Commito et al. 1995, Thrush et al. 1996). These intertidal sites contain at the seabed), also varied with degree of disturbance (Fig. 7). The highest probability of occurrence of $T$. lubrica and the mud crab $H$. crassa was in habitats with low wind-wave disturbance, in agreement with their dominance in deep subtidal sites and sheltered tidal estuary habitats, where wind-wave disturbance is limited. The probability of occurrence of bivalve species such as $M$. liliana and $A$. stutchburyi increased with increasing wind-wave disturbance, also in agreement with their dominance in the physically dynamic, outer-embayment habitats. only small percentages of mud $(5.8 \%)$ because of wind-generated wave activity that increases physical disturbance at the sediment surface and hence tends to resuspend and mobilise finer particles. Among the validation data, the Manukau sites therefore have the greatest wind-generated wave disturbance, with high average orbital speed $\left(U_{\mathrm{b}}{ }^{3}=0.24\right)$ and high critical orbital-wave speed $\left(U_{\mathrm{w}, \mathrm{crit}}=0.40\right)$ recorded at the seabed. Puhinui is a small sheltered tidal creek within the Manukau estuary, with low physical disturbance by waves $\left(U_{\mathrm{b}}{ }^{3}=0.01\right.$, ebb and flood velocity $\left.=0.02\right)$ and 
hence correspondingly high mud contents of the sediments $(95 \%)$. The Mahurangi estuary is a shallow $(<15 \mathrm{~m})$, narrow estuary that experiences less physical disturbance than Manukau Harbour. However, this estuary experiences greater tidal velocities and greater flushing than the sheltered Puhinui Creek sites. Large-scale variables derived from the NZED indicate that the Mahurangi estuary has higher percentages of rainfall and runoff than the other sites, while the Manukua has a greater coastline length and catchment area (Table 5). Puhinui is a small tidal creek with a higher percentage of intertidal and mangrove habitat.

\section{Observed distribution of macrobenthos}

We again used multivariate techniques to assess the species habitattype-associations observed at the validation sites. Based on species composition, sites were separated predominately by estuary type (Fig. 8). As discussed in the foregoing subsection, each estuary displayed differing levels of physical forcing, sediment types, and large-scale forcing. Again, these distinct habitats were found to support distinct macrofaunal communities (Table 6). The differences in macrobenthic assemblages between habitats ranged from 64 to $89 \%$ (Table 4 ). The Manukau and Mahurangi intertidal sites had the most similar macrobenthic assemblages with the lowest dissimilarity of $64.3 \%$, while the mudflat communities at Puhinui were the most dissimilar from the high diversity communities recorded at Manukua. The top 5 dominant taxa in the Manukau estuary (a physically dynamic environment comprised of intertidal sandflats) included the bivalves Macomona liliana and Nucula hartvigiana, the polychaetes Heteromastus filiformis and Magelona dakini, and nemerteans. The Mahurangi intertidal sites, which were most similar to Manukau, were also dominated by $M$. liliana, $N$. hartvigiana and $H$. filiformis. Dominant species at the sheltered Puhinui sites varied considerably, and comprised oligochaetes, the mud crab Helice crassa,

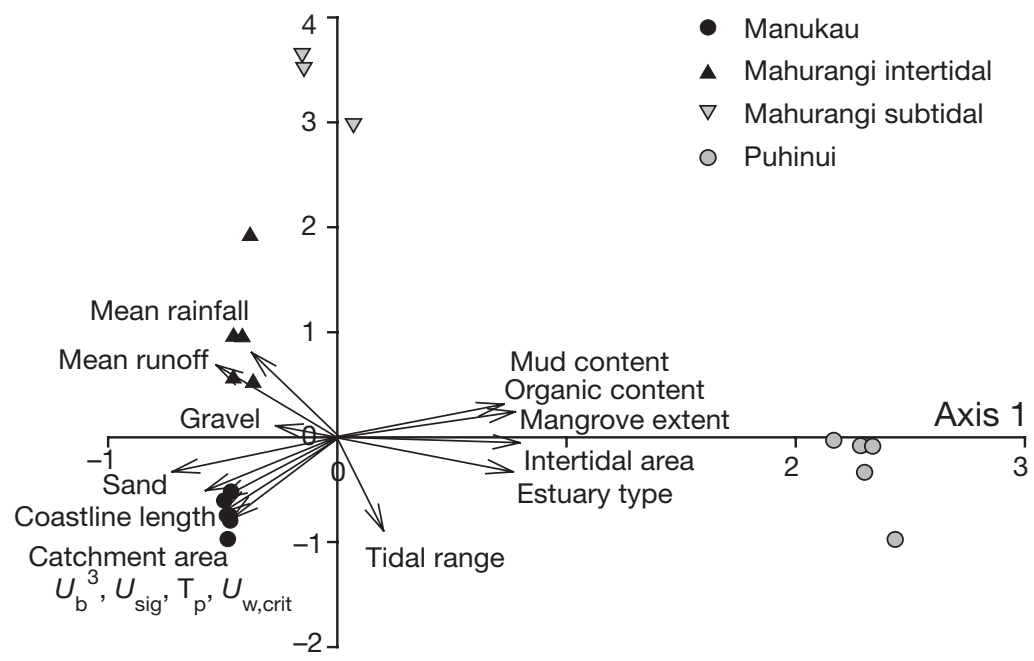

Axis 2

Fig. 8. Canonical correspondence analysis of environmental variables (arrows) and sampling sites (see legend) using macrofaunal abundance data from validation estuaries Manukau, Mahurangi and Puhinui. Abbreviations as in Table 1

Table 6. Rankings of 5 most dominant macrofauna in Manukau, Mahurangi and Puhinui estuaries determined by similarity percentage analysis

\begin{tabular}{|lccc|}
\hline $\begin{array}{l}\text { Habitat and dominant } \\
\text { taxa }\end{array}$ & $\begin{array}{c}\text { Faunal } \\
\text { group }\end{array}$ & & $\begin{array}{c}\text { Cumulative } \% \\
\text { explained }\end{array}$ \\
\hline Manukau & & & \\
Macomona liliana & Bivalve & 5.94 & 5.94 \\
$\quad$ Heteromastus filiformis & Polychaete & 5.71 & 11.64 \\
Magelona dakini & Polychaete & 5.36 & 17.00 \\
Nucula hartvigiana & Bivalve & 4.62 & 21.62 \\
Nemertean & & 4.10 & 25.72 \\
Mahurangi Intertidal & & & \\
Heteromastus filiformis & Polychaete & 7.92 & 7.92 \\
Nucula hartvigiana & Bivalve & 6.98 & 14.89 \\
Boccardia syrtis & Polychaete & 6.23 & 21.12 \\
Cossura sp. & Polychaete & 5.96 & 27.08 \\
Macomona liliana & Bivalve & 5.85 & 32.93 \\
Mahurangi Subtidal & & & \\
Theora lubrica & Bivalve & 12.64 & 12.64 \\
Lepidontidae sp. & Polychaete & 9.15 & 21.80 \\
Oligochaeta & Oligochaete & 8.31 & 30.11 \\
Prionospio sp. & Polychaete & 8.18 & 38.29 \\
Torridoharpinia hurylei & Amphipod & 8.18 & 46.48 \\
Puhinui & & \\
Oligochaeta & Oligochaete & 15.77 & 15.77 \\
Scolecolepides sp. & Polychaete & 10.34 & 26.11 \\
Helice crassa & Crab & 9.06 & 35.16 \\
Capitellid & Polychaete & 8.32 & 43.48 \\
Phoxocephalid & Amphipod & 7.86 & 51.34 \\
& & & \\
\hline
\end{tabular}

2 polychaetes and phoxocephalid amphipods. At the subtidal Mahurangi sites, the dominant species comprised Theora lubrica, the polychaetes Lepidontidae sp. and Prionospio sp., oligochaetes, and the amphipod Torridoharpinia hurylei. The species recorded in these contrasting environmental habitats are similar to those recorded in the contrasting habitats at Whitford. For 


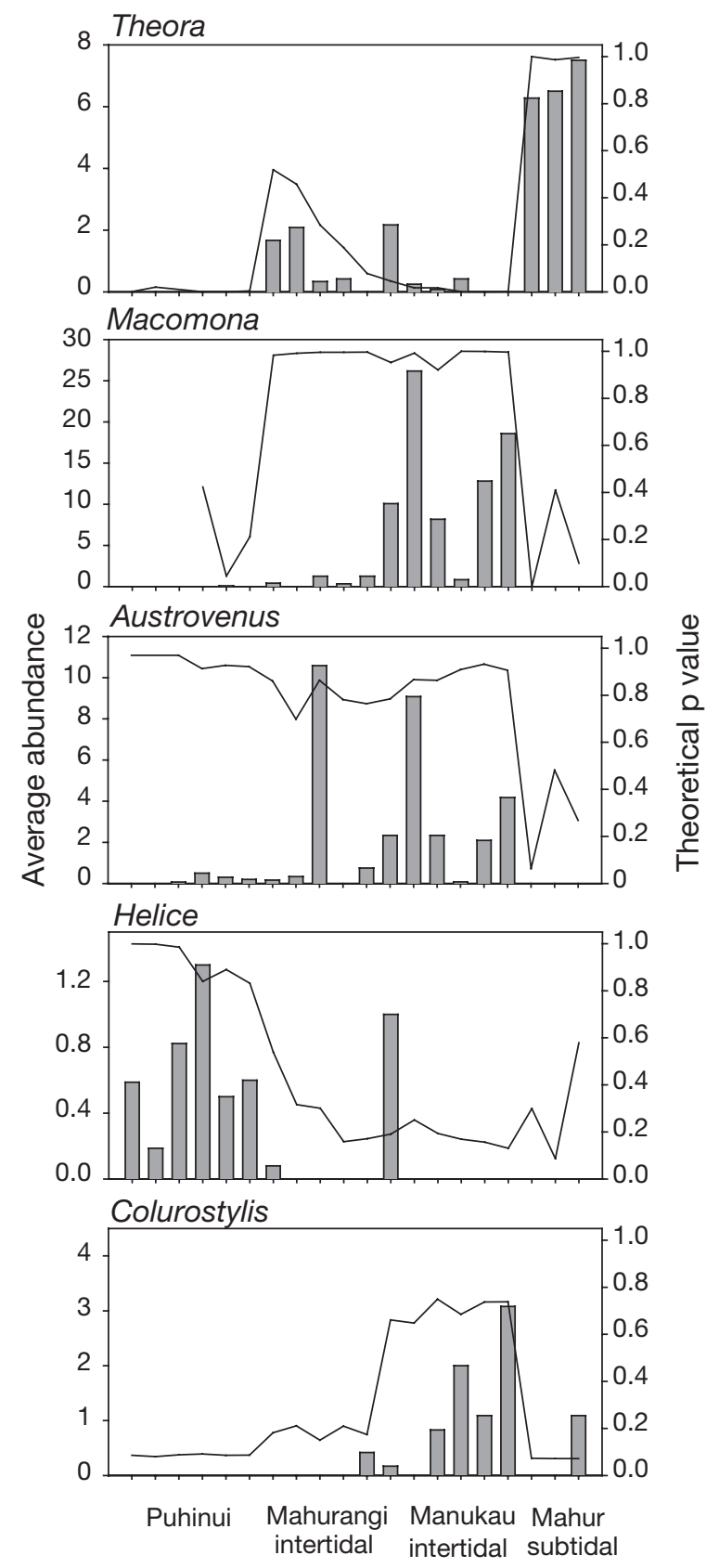

Fig. 9. Observed abundances (bars; mean per core) of 5 macrobenthic species compared to probabilities of occurrence $\left(p_{\text {; }}\right.$ solid line) determined by logistic regression. Full specific names in legend to Fig. 3

example, there is a predominance of suspension-feeding bivalves in sandy intertidal habitats, while in muddy sheltered sites the community changes to a predominance of oligochaetes and other head-down deposit-feeding polychaetes such as $H$. filiformis, along with crabs and amphipods.

Trends in the average diversity and abundance recorded for the various Whitford habitats were also observed for the validation data. Again, the upper muddy estuarine habitats such as the Puhinui sites had the lowest species diversity. Interestingly, like the Whitford subtidal shallow habitat, the Mahurangi subtidal sites also had correspondingly low species diversity. These sites are also likely to experience prolonged exposure to suspended sediments, as reflected by the elevated sediment mud content. Again, like the Whitford 'embayment intertidal' habitat, the exposed intertidal sandflats of the Manukau estuary had the highest average diversity and also the greatest abundances of individuals. The macrofaunal abundance for the Mahurangi intertidal sites was also similarly high.

\section{Model validation results}

Fig. 9 shows the calculated probability of occurrence of macrobenthic species in relation to their observed abundances for a few representative example species. The accuracy of the model varied dependent on the species. For example, for the invasive bivalve species Theora lubrica the model indicated an increased probability of occurrence with increasing depth, which was consistent with the observed distributions of T. lubrica at deeper subtidal sites in the Mahurangi estuary. Species such as the crustacean Colurostylis lemurum were also well predicted by the model, which indicated an increased probability of occurrence at sandy intertidal sites that was also consistent with the observed distributions of higher abundance at the sandy Manukau and Mahurangi intertidal sites. However, for ubiquitous species or large mobile macrofauna, the model predictions of occurrence were not as sensitive. For example, the cockle Austrovenus stutchburyi is a ubiquitous species that has a broad tolerance range to varying environmental conditions; hence, the model predicted a high probability of occurrence across all validation sites except for Mahurangi subtidal sites. While $A$. stutchburyi was recorded across all other sites, the actual observed densities recorded at the sheltered muddy Puhinui sites were very low in comparison to the model predictions. We were also unable to develop sensitive models for large mobile species such as the mud crab Helice crassa, because of difficulties in estimating crab density using small-scale, core sample information.

\section{DISCUSSION}

\section{Logistic regression and model predictions}

The aim of this work was to investigate the applicability of the models developed by Ysebaert et al. (2002) in the Schelde estuary, the Netherlands, to other, quite 
different estuarine systems. We successfully developed models relating the distribution of common intertidal macrofauna to changing environmental variables such as sediment characteristics, depth/elevation, tidal currents and wind-wave disturbance. We therefore found that logistic regression is a useful approach for predicting the occurrence of species under varying environmental conditions.

Our modelling approach was capable of predicting macrobenthic species distributions with a relatively high degree of success, with the percentage of correct predictions ranging from 59 to $97 \%$. However, similar to Ysebaert et al. (2002), we were able to predict the probability of occurrence for some species better than for others. For example, we were unable to develop sensitive models for some ubiquitous species or for large mobile macrofauna. Ysebaert et al. (2002) identified a number of causes for this variability in success, including lack of fine-scale information on the macrobenthic populations. For example, the distributions of species that are rare, large, or highly clumped tend to be harder to accurately predict because of difficulties in adequately sampling such species with small-scale core techniques. We also found that the distribution of large and highly mobile species such as the mud crab Helice crassa was more difficult to accurately predict using logistic modelling based on core-sample data. Another species for which we were unable to develop a sensitive model was the cockle Austrovenus stutchburyi. A. stutchburyi is a ubiquitous species that can tolerate a range of environmental conditions. Thrush et al. (2003) considered that species which exhibit broad tolerance to environmental conditions are unlikely to be species for which sensitive models can be developed based on presence/absence alone, and suggested modelling changes in the abundance as well as occurrence of such species to reveal extra information on the sensitivity of the species to environmental factors. The use of density and biomass models as well as small-scale information on the distributions of such species would potentially lead to an improvement of the prediction success. However, in the absence of deterministic models, broad-scale statistical models that are able to forecast the distribution of species are useful from both an ecological and environmental perspective.

Model comparisons of the relative sensitivity of different species revealed wide variations in response to changes in environmental conditions. For example, even functionally similar species such as surface, deposit-feeding, spionid polychaetes showed varying sensitivities to changes in sediment mud-content. Aonides oxycephala was sensitive to increased mud content, while Aquilaspio aucklandica appeared to have a broader tolerance in this respect. This finding was similar to that of Thrush et al. (2003), who noted that such species-specific differences in habitat preference have important implications for conclusions drawn from studies of low taxonomic resolution, or aggregative indices of ecological change or ecosystem 'health'.

\section{Community changes}

Community-level changes with increases in sediment content revealed interesting patterns. In this study, diversity was reduced in habitats with elevated mud content of the sediment, while the diversity and abundance of macrofauna was greatest for exposed intertidal sandflats. We also observed functional differences in the sensitivity of benthic animals to increased terrigeneous sedimentation. In general, the functionally important group of suspension-feeding bivalves were sensitive to increases in fine sediments. Our findings are consistent with those of other field studies that have investigated effects of sedimentation on benthic community composition and have demonstrated clear reductions in diversity, and implications for the loss of key functional groups such as suspension-feeding populations (Ellis et al. 2002, Norkko et al. 2002, Thrush et al. 2003). Interestingly, our finding of decreases in the abundance of benthic macrofauna in areas of high silt/clay content differs from those of many studies which frequently observed communities with reduced diversity yet higher densities in muddy intertidal habitats. However, the pattern recorded in our study may reflect our focus on macrofauna retained on a $0.5 \mathrm{~mm}$ sieve.

Macrofauna influence sediment stability, watercolumn turbidity, and nutrient- and carbon-processing (Herman et al. 1999), and are an important food resource for epibenthic crustaceans, fishes and birds. Management of these resources requires the ability to predict the dynamics of their populations (Ysebaert et al. 2002). The ability to forecast changes in the spatial distribution of species also affords important insight into the threat that loss of habitat diversity may pose to biological diversity and ecosystem health (Thrush et al. 2003).

\section{Classification}

Using ordination techniques, we investigated relationships between higher level physical variables from the NZED classification system and localised differences in habitat-species associations. The NZED classifies estuaries according to components of the physi- 
cal environment that broadly control hydrodynamic, sedimentological and chemical processes (Hume \& Snelder 2001). The classes range from system-level climate and oceanic water-mass control, to control of hydrodynamic processes by basin morphometry and river and oceanic forcing, and finally the influence of catchments draining to the estuary on sedimentological and chemical processes. The physical character of estuaries is presumed to limit variability in many properties, such as biological communities, water chemistry, and sensitivity to certain types of perturbation (e.g. increased sediment input at the level of whole estuaries). Hence, the database presented herein provides unique information for testing macroecological relationships such as species-area trends and bodysize/habitat associations.

Macroecology is a useful approach for predicting ecological responses to higher order variables, because it takes a top-down view of ecological systems and seeks to identify general results at the expense of detail (Brown 1995). However, while it is an iterative process facilitating the identification of mechanisms operating at the broad-scale, the strong emphasis on statistical relationships requires the need for adequately large databases. For marine benthic ecosystems, data is often sparse and often not available for particular habitat types. While we were able to identify relationships between higher-level variables such as estuary type, basin morphometry and catchment draining processes in driving macrobenthic community differences, we were unable to fully test the utility of this approach, because of differences in the scale at which macrobenthic data is collected (sites within an estuary) and the scale of the higher-level physical variables (variables descriptive of whole facies or subenvironments in an estuary). A further consideration is that while we were able to partition the macrobenthic communities within estuaries on the basis of broad-scale habitat characteristics, we found a wide variety of relationships between abundance and physical variables for individual species. Even for functionally similar species, such as the spionid polychaetes Aonides oxycephala and Austrovenus stutchburyi, we found quite different sensitivities and variations in response to sediment mud content.

While adequate data sets are limited, investigations of species-specific responses to higher level classification variables would provide important insights into the utility of this approach for predicting responses to broad-scale habitat changes. However, in the light of our findings, development of these models would require careful consideration of speciesspecific, natural history information and consideration of the interaction of processes operating at different scales.

\section{CONCLUSIONS}

Broad-scale statistical models that are able to forecast the distribution of species are useful from both an ecological and environmental perspective. Statistical models are unable to provide insight into the mechanistic controls on species distributions, but rather are descriptors of the distribution patterns of species as a function of all abiotic variables measured, regardless of direct or indirect dependence on these variables. Habitat-dependent responses are likely to be complex interactions between life history, feeding, reproduction and mobility of species, and hydrodynamic and biogeochemical processes, and will require detailed study to resolve (Snelgrove \& Butman 1994). However, where patterns of distribution are strongly and directly coupled to physiocochemical processes, as is the case at the estuarine macro- and meso-scales, such modelling approaches are capable of predicting macrobenthic species distributions with a relatively high degree of accuracy.

Acknowledgements. We thank Rick Liefting for calculating the NZED variables and Richard Gorman for calculating the tidal velocities. Comments by Judi Hewitt greatly helped to improve the manuscript. We also thank Greig Funnell, Vonda Cummings, Judi Hewitt and Don Morrissey for providing the validation data sets. This research was funded by the National Institute for Coastal and Marine Management (RIKZ project RKS889) the Netherlands, the Auckland Regional Council, and the New Zealand Foundation for Research Science and Technology (FRST-C01X0307).

\section{LITERATURE CITED}

Bailey RG (1983) Delineation of ecosystem regions. Environ Manage 7:365-373

Bell RG, Hume TM, Dolphin TJ, Green MO, Walters RA (1997) Characterisation of physical environmental factors on an intertidal sandflat, Manukau Harbour, New Zealand. J Exp Mar Biol Ecol 216:11-31

Black KP (1995) The hydrodynamic model 3DD and support software. Occasional report 19. Department of Earth Sciences, University of Waikato

Black KP (1997) WGEN3DD, Wave generation model for enclosed water bodies and support software. University of Waikato

Brown JH (1995) Macroecology. University of Chicago, Chicago, IL

Commito JA, Thrush SF, Pridmore RD, Hewitt JE, Cummings VJ (1995) Dispersal dynamics in wind-driven benthic system. Limnol Oceanogr 40(8):1513-1518

Cox DR (1970) The analysis of binary data. Methuen, London

Day JW Jr, Hall AS, Kemp WM, Yanez-Arancibia A (1989) Estuarine ecology. John Wiley, New York

Ellis J, Cummings V, Hewitt J, Thrush S, Norkko A (2002) Determining effects of suspended sediment on condition of a suspension feeding bivalve (Atrina zelandica): results of a survey, a laboratory experiment and a field transplant experiment. J Exp Mar Biol Ecol 267:147-174 
Ellis J, Nicholls P, Craggs R, Hofstra D, Hewitt J (2004) Effects of terrigenous sedimentation on mangrove physiology and associated macrobenthic communities. Mar Ecol Prog Ser 270:71-82

Herman PMJ, Middelburg JJ, van de Koppel J, Heip CHR (1999) Ecology of estuarine macrobenthos. Adv Ecol Res 29:195-240

Hosmer DW, Lemeshow S (1989) Applied logistic regression. John Wiley, New York

Hume T, Snelder T (2001) Marine typology down-under. LOICZ Newsl 19. Land ocean interactions in the coastal zone. International Project Office, Den Burg

Klijn F, Udo de Haes HA (1994) A hierarchical approach to ecosystems and its implications for ecological land classification. Landsc Ecol 9:89-104

Komar PD, Miller MC (1975) On the comparison between the threshold of sediment motion under waves and unidirectional currents with a discussion of the practical evaluation of the threshold. J Sediment Petrol 45:362-367

Levin L, Boesch DF, Covich A, Dahm C and 8 others (2001) The function of marine critical transition zones and the importance of sediment biodiversity. Ecosystems 4: $430-451$

Norkko A, Thrush SF, Hewitt JE, Norkko J and 5 others (2002) Smothering of estuarine sediments by terrigenous clay: the role of wind-wave disturbance and bioturbation in site-dependent recovery. Mar Ecol Prog Ser 234:23-42

Oldman J, Swales A (1999) Maungamaungaroa estuary numerical modelling and sedimentation. Client report ARC70224. National Institute of Water and Atmospheric Research, Hamilton

Pearson TH, Rosenberg R (1978) Macrobenthic succession in relation to organic enrichment and pollution of the marine environment. Oceanogr Mar Biol Annu Rev 16:229-311

Rhoads DC, Young DK (1970) The influence of deposit feeding organisms on sediment stability and community trophic structure. J Mar Res 28:150-178

Sartory DP (1982) Spectophotometric analysis of chlorophyll a in freshwater phytoplankton. Tech Rep 115. Hydrological Research Institute, Pretoria

Editorial responsibility: John Gray (Contributing Editor), Oslo, Norway
SAS Institute (1989) SAS/SYSTAT users guide, Version 6, 4th edn. SAS Institute, Cary, NC

Snelgrove PVR, Butman CA (1994) Animal-sediment relationships revisited: cause versus effect. Oceanogr Mar Biol Annu Rev 32:111-177

Ter Braak CJF (1986) Canonical correspondence analysis: a new eigenvector technique for multivariate direct gradient analysis. Ecology 67:1167-1179

Ter Braak CJF (1987) The analysis of vegetation-environment relationship by canonical correspondence analysis. Vegetatio 69:69-77

Thorson G (1950) Reproduction and larval ecology of marine bottom invertebrates. Biol Rev 25:1-45

Thrush SF, Whitlatch RB, Pridmore RD, Hewitt JE, Cummings VJ, Maskery M (1996) Scale-dependent recolonisation: the role of sediment stability in a dynamic sandflat habitat. Ecology 77:2472-2487

Thrush SF, Hewitt JE, Norkko A, Nicholls PE, Funnell GA, Ellis JI (2003) Habitat change in estuaries: predicting broad-scale responses of intertidal macrofauna to sediment mud content. Mar Ecol Prog Ser 263:101-112

Turner SJ, Thrush SF, Pridmore RD, Hewitt JE, Cummings VJ, Maskery M (1995) Are soft-sediment communities stable? An example from a windy harbour. Mar Ecol Prog Ser 120:219-230

Warwick RM (1986) A new method for detecting pollution effects on marine macrobenthic communities. Mar Biol 92:557-562

Warwick RM, Goss-Custard JD, Kirby R, George CL, Pope ND, Rowden AA (1991) Static and dynamic environmental factors determining the community structure of estuarine macrobenthos in SW Britain: Why is the Severn Estuary different? J Appl Ecol 28:329-345

Whelan MB, Hume TM, Sagar PM, Shankar U, Liefting R (2003) Relationships between physical characteristics of estuaries and the size and diversity of wader populations in the North Island of New Zealand. Notornis 50:11-22

Ysebaert T, Meire P, Herman P, Verbeek H (2002) Macrobenthic species response surfaces along estuarine gradients: prediction by logistic regression. Mar Ecol Prog Ser 225:79-95

Submitted: January 5, 2005; Accepted: October 28, 2005 Proofs received from author(s): June 1, 2006 